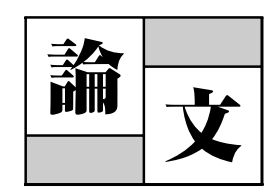

\title{
射出成形と射出圧縮成形における成形品内部構造の相違
}

\author{
納 土賢 悟*1 ${ }^{* 1}$ 滝雅 也*2 演 田 泰 以*2
}

\section{Difference in Internal Structure of Products Obtained in Injection Molding and Injection Compression Molding}

\begin{abstract}
Nodo, Kengo*1/Kotaki, Masaya*2/Hamada, Hiroyuki ${ }^{* 2}$
Injection compression molding is an effective process to solve molding defects such as sinking, warpage, and so on. However there are very few research reports on injection compression molding. In this process, the internal structure of products is very important. In this study, the difference in the morphology between normal injection molding and injection press molding, which is a kind of injection compression molding, was examined using PC/ABS. There are different internal structures observed in skin and core in normal injection molding, whereas in injection press molding the internal structure of both layers is almost the same.
\end{abstract}

Key words : PC/ABS/Injection compression molding/Injection press molding/Internal structure

\section{1. 緒言}

近年, 射出成形品への高付加価值化, 高機能化などの要 求から, 様々な新しい成形材料が開発され, 成形加工技術, 型技術も著しく進歩してきた。 それに伴い射出成形機の機 能も進化し，サンドイッチ成形や，射出圧縮成形などの新 しい成形技術が確立されてきている.

射出圧縮成形は，成形機の型締動作を利用することによ り材料を金型内に充填できるため，従来の射出成形に比べ, 低い射出圧力で比較的大型な成形品の成形が可能となる。 これにより，成形機のダウンサイジング化が可能となる. したがって，射出圧縮成形は型締動作による低圧成形法と 位置づけられている1).また, 型内圧力の減少による成形 品内の残留応力低下と, 圧縮による圧力の均等化によるソ リやひずみの低減, 寸法精度の向上, 転写性の向上などが 期待できると言われている，以上のようなことから，射出 圧縮成形はコンパクトディスクやレンズ，導光板などの光 学部品, 歯車などの精密成形部品, 自動車のドアパネルや ダッシュボードなど大型薄物成形品の成形に使われている.

\footnotetext{
${ }^{* 1}$ (秼)ノード製作所

大阪市旭区生江 1-8-20（５535-0004）

Nodo Seisakusho Co., LTD

8-20 Ichome, Ikue Asahi-ku, Osaka, 535-0004, Japan

*2 国立大学法人 京都工芸繊維大学

Kyoto Institute of Technology

2007.5. 7 受理
}

また，IC カードや PC 基盤の封止に射出圧縮成形を用い る場合もある。

最近では, 燃料電池の重要な部品であるセパレータの成 形に射出圧縮成形を応用する試みや゙2), ポリプロピレン (PP), ポリエチレンテレフタレート (PET) などの結晶 性樹脂の結晶化を射出圧縮成形により制御し, 成形品の品 質向上を得るという研究報告もされている ${ }^{3), 4)}$. また, CAE 技術の発達により射出圧縮成形における樹脂流動解析を行 うソフトウエアも開発され ${ }^{5)}$, 射出圧縮成形が，実際に成 形現場の様々な場面で活用されている.

しかし，射出圧縮成形に関する文献や資料がまだ少なく， 特に, 射出圧縮成形品の内部構造や流動特性, 物性に関し て不明な点が多いのが現状である。

そこで, 射出圧縮成形品の内部構造, 流動特性, 物性を 把握することは射出圧縮成形における成形技術向上のため に重要であると考え, 本研究では, 射出圧縮成形の一技法 であり, 成形品形状の賦形の大部分を圧縮で行う射出プレ ス成形を用いて, 通常の射出成形と成形品における内部構 造の違いについて検討を行った。

\section{2. 実験方法}

\section{1 材料}

実験に用いた材料は，PC（ユーピロン S-3000 N ：三菱 エンジニアリングプラスチックス侏）および ABS（TEX $170 \mathrm{NP}$ ：テクノポリマー(侏) をベント式一軸押出機（藤 谷機械製作所製）により重量比 $6: 4$ の比率でブレンドし 


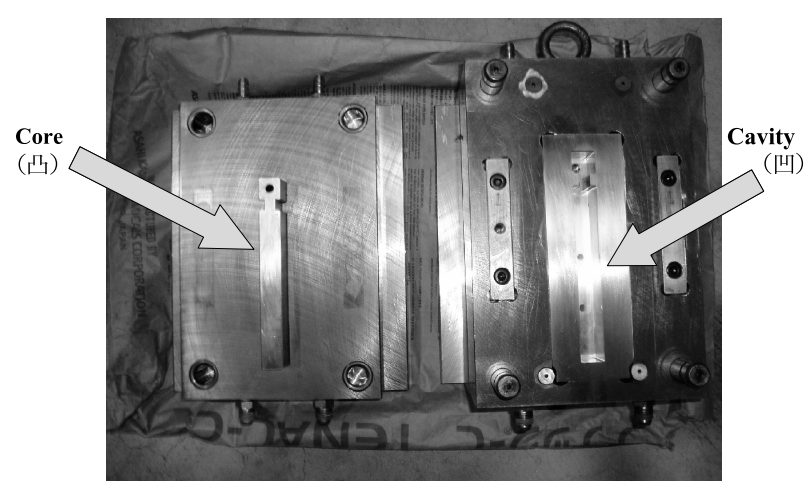

Fig. 1 Mold for injection press molding

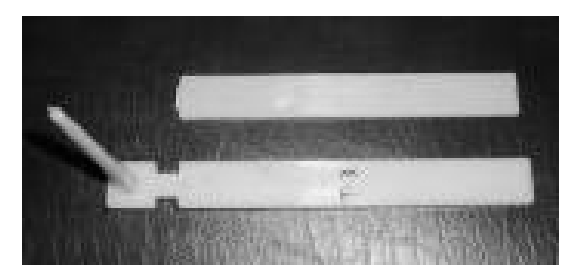

$\mathrm{t}=3 \mathrm{~mm}$

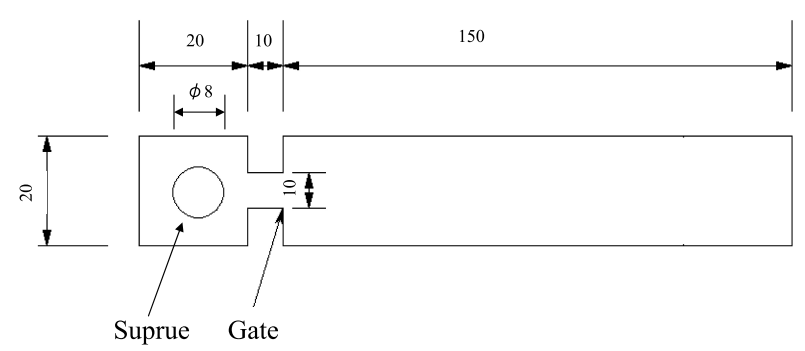

Fig. 2 PC/ABS Flat board

た $\mathrm{PC} / \mathrm{ABS}$ 材である。混練条件は, シリンダー温度 $260^{\circ} \mathrm{C}$, スクリュー回転数を $260 \mathrm{rpm}$ とした。

$\mathrm{PC} / \mathrm{ABS}$ 成形品に硫酸と二クロム酸混合溶液による エッチング処理を施すことにより，ABSリッチな部分が 溶出され空孔となり成形品の内部構造を観察することがで きる.

\section{2 成形実験及び内部構造観察}

成形実験には射出圧縮，射出プレス成形機能を搭載した 電動サーボ射出成形機（MD 100 S II : (侏)ニイガタマシン テクノ製型締力 $100 \mathrm{t}$ ）を用いて, 図 1 に示す射出プレス 成形用に設計された印籠構造の金型で, 図 2 の長さ $150 \mathrm{~mm}$, 幅 $20 \mathrm{~mm}$, 厚さ $3 \mathrm{~mm}$ の長方形状の平板成形品 を作製した.

成形条件は射出成形, 射出プレス成形ともに, シリンダー 温度 $270 \sim 260^{\circ} \mathrm{C}$, 射出速度 $100 \mathrm{~mm} / \mathrm{sec}$, 金型温度 $80^{\circ} \mathrm{C}$, 射出時間 $8 \mathrm{sec}$ ，冷却時間 $20 \mathrm{sec}$ とした.

図 3 に示すように射出プレス成形は最初から任意の位置 で金型を開いた状態で射出動作を開始し，型締めによる圧 縮動作で，成形品形状の賦形の大部分を行う成形法である。 例えば，肉厚 $3 \mathrm{~mm}$ の成形品を圧縮量 $5 \mathrm{~mm}$ の射出プレス 成形で作成する場合, $8 \mathrm{~mm}$ の空間に樹脂を充填して $5 \mathrm{~mm}$ 圧縮することによって最終肉厚 $3 \mathrm{~mm}$ の成形品を得ること ができる．この場合，圧縮量とは金型の初期開き量であり， 射出プレス成形に扔ける重要な成形パラメーターである. 射出プレス成形では射出動作による樹脂流動領域と圧縮動

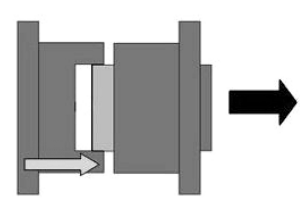

1

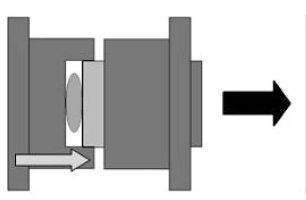

2

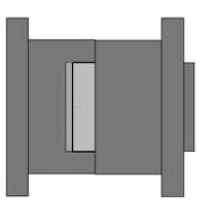

3
Fig. 3 Process of injection press molding

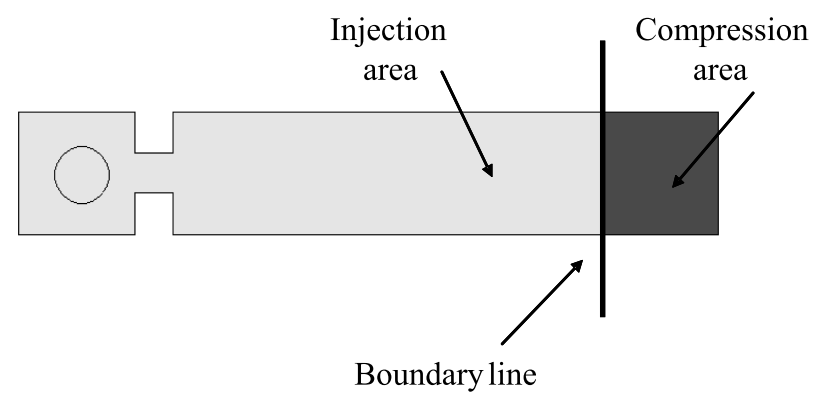

Fig. 4 Area recognition and boundary

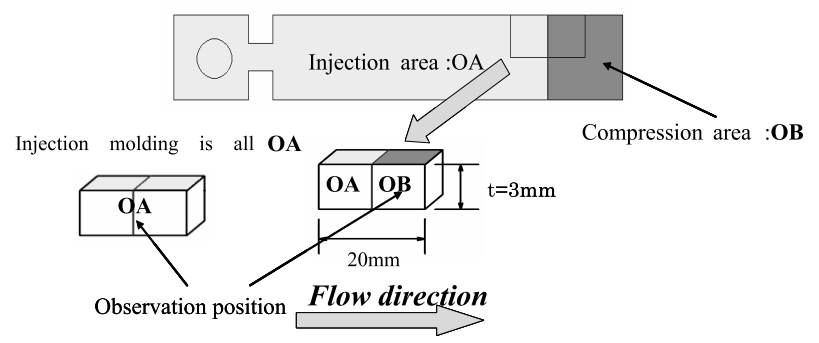

Fig. 5 Sample preparation for SEM observation

作による樹脂流動領域が存在する。これに対し，射出成形 では成形品全域が射出流動領域になる。

実験は従来の射出成形に扔ける保圧工程を行わず，型盤 による压縮圧力を加え成形を行った。つまり，保圧切り替 え位置にスクリューが到達した時点で保圧工程を停止し， 圧縮動作が開始するように成形機を設定した。また，射出 流動領域と圧縮流動領域の境界を認識するために，射出成 形で得られた成形品の体積分の樹脂を型内に射出し，保圧 切り替え位置で射出動作を停止させ，ショートショット成 形品を作製し，図 4 に示すように流動の先端を境界位置と して測定した. 圧縮条件は圧縮量 $1 \mathrm{~mm}$ と $5 \mathrm{~mm} の 2$ 条件 と圧縮移行時間 $0.1 \mathrm{sec}$ と $3.0 \mathrm{sec}$ の 2 条件の計 4 条件, 射出成形を加えると計 5 種類の条件で成形を行った．圧縮 移行時間とは樹脂充填完了後の型締めによる圧縮動作開始 から完全に型締めされるまでの設定移動時間である。した がって，圧縮移行時間が $0.1 \mathrm{sec}$ と $3.0 \mathrm{sec} て ゙ は ， 0.1 \mathrm{sec}$ の方が型締め動作が速く行われる.

ショートショット成形品の観察により压縮量 $1 \mathrm{~mm}$ の場 合，射出流動領域と圧縮流動領域の境界はゲートから 135 $\mathrm{mm}$ の位置であることがわかった。この位置より圧縮によ る流動が開始され，成形品末端の $150 \mathrm{~mm}$ の位置まで樹脂 が充填される. 圧縮量 $5 \mathrm{~mm}$ の場合の境界位置はゲートか ら $94 \mathrm{~mm}$ であった。各条件の境界位置を表 1 に示す。

図 5 に示すように, ここでは射出流動領域を $\mathrm{OA}$ 部, 圧縮流動領域を $\mathrm{OB}$ 部とし, 各領域の内部構造を観察する 
ため境界を中心に約 $20 \mathrm{~mm}$ の試験片を切り出し観察面に 前述のエッチング処理を施して観察した。観察位置は境界 から約 $8 \mathrm{~mm}$ の位置の $\mathrm{OB}$ 部の断面であり走査電子顕微鏡 （SEM）で観察した。射出成形品の場合, すべて射出流動 領域であるため $\mathrm{OA}$ 部として各圧縮条件の境界位置付近 を観察した。

\section{3. 実験結果及び考察}

\section{1 内部構造観察}

図 6 , 図 7 に射出成形品と圧縮量 $1 \mathrm{~mm}$ の射出プレス成 形品の断面写真を示す。ここで成形品表面から厚さ方向に 約 $200 \mu \mathrm{m}$ までの層をスキン層と呼び, 成形品板厚方向の 中心部分，約 $200 \mu \mathrm{m}$ の層をコア層と呼ぶことにする. 写 真中，空孔になっている部分はエッチングにより ABSが 溶け出した ABS リッチ相であり, 樹脂が残存している部 分が PC 相である.

射出成形品のスキン層では，流動方向に変形した細長い 空孔が観察された。一方，コア層では丸い空孔が観察され， スキン層とは大きく異なる内部構造を示した.

圧縮量 $1 \mathrm{~mm}$ の射出プレス成形品では, 圧縮移行時間 $0.1 \mathrm{sec} ， 3.0 \mathrm{sec}$ ともに，スキン層においては射出成形品 と同様に流動方向に変形した細長い空孔が観察された。コ ア層では, 射出成形品に比べ, 若干, 空孔が押しつぶされ て偏平化している様子が観察された. しかし, 圧縮移行時 間の違いによる内部構造の顕著な違いは認められなかった。

Table 1 Injection press molding conditions and boundary

\begin{tabular}{c|c|c|cr}
\hline $\begin{array}{c}\text { Thickness } \\
\mathrm{t}(\mathrm{mm})\end{array}$ & $\begin{array}{c}\text { Amount of } \\
\text { compression } \\
\text { (The clearance of } \\
\text { mold })(\mathrm{mm})\end{array}$ & $\begin{array}{c}\text { Boundary of } \\
\text { injection area } \\
\text { and compression } \\
\text { areal }(\mathrm{mm})\end{array}$ & $\begin{array}{c}\text { Finish } \\
\text { compression } \\
\text { time } \\
(\mathrm{sec})\end{array}$ \\
\hline & 0 & $150 \mathrm{~mm}$ & & 0 \\
\cline { 2 - 4 } & 1 & $135 \mathrm{~mm}$ & & \\
\cline { 2 - 3 } & 5 & $94 \mathrm{~mm}$ & $0.1 \quad 3$ \\
\hline
\end{tabular}

図 8, 図 9 に圧縮量 $5 \mathrm{~mm}$, 圧縮移行時間 $0.1 \mathrm{sec}$ と $3 \mathrm{sec}$ の射出プレス成形品と射出成形品の断面写真を示す. スキ ン層においては射出成形品と同様に流動方向に変形した細 長い空孔が観察された。 しかし，コア層の内部構造は射出 成形品と大きく異なり，空孔が流動方向に細長く変形して いる様子が観察された。これは前述の圧縮量 $1 \mathrm{~mm}$ とも異 なっている. すなわち, 射出プレス成形品の場合, スキン 層とコア層が非常に類似した内部構造を示していることに なる。また，圧縮移行時間の違いによる構造の違いは，認 められなかった.このことから, 圧縮移行時間よりも圧縮 量の差が成形品の内部構造に影響していると推察できる.

このように射出プレス成形では，作成する成形品肉厚よ りも厚い空間（キャビティ）に樹脂が射出された後に, 型 締動作により樹脂が圧縮される. したがって, 圧縮動作に より樹脂が押しつぶされて構造が偏平化し, 板厚方向に均 一な内部構造が得られたものと考えられる。
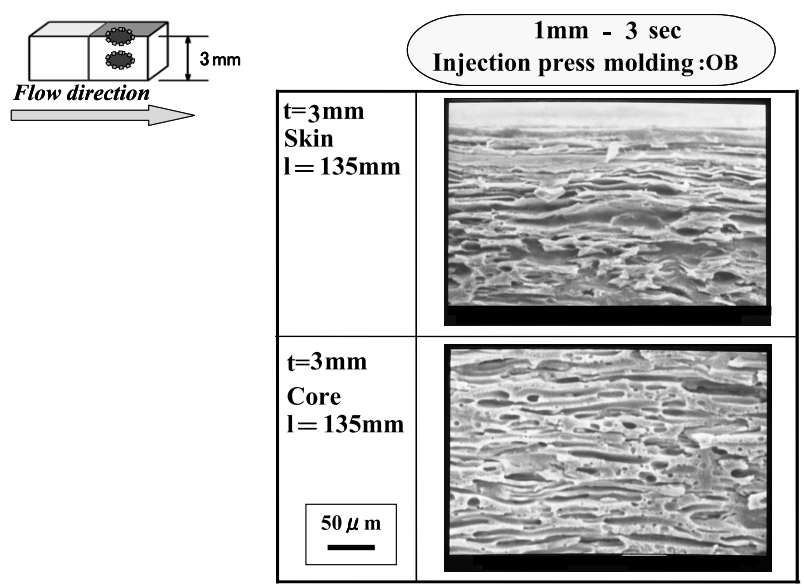

Fig. 7 SEM micrographs of normal injection molding and injection press molding with $3 \mathrm{~mm}$ thickness (compression distance : $1 \mathrm{~mm}$, compression time : $3 \mathrm{sec})$.

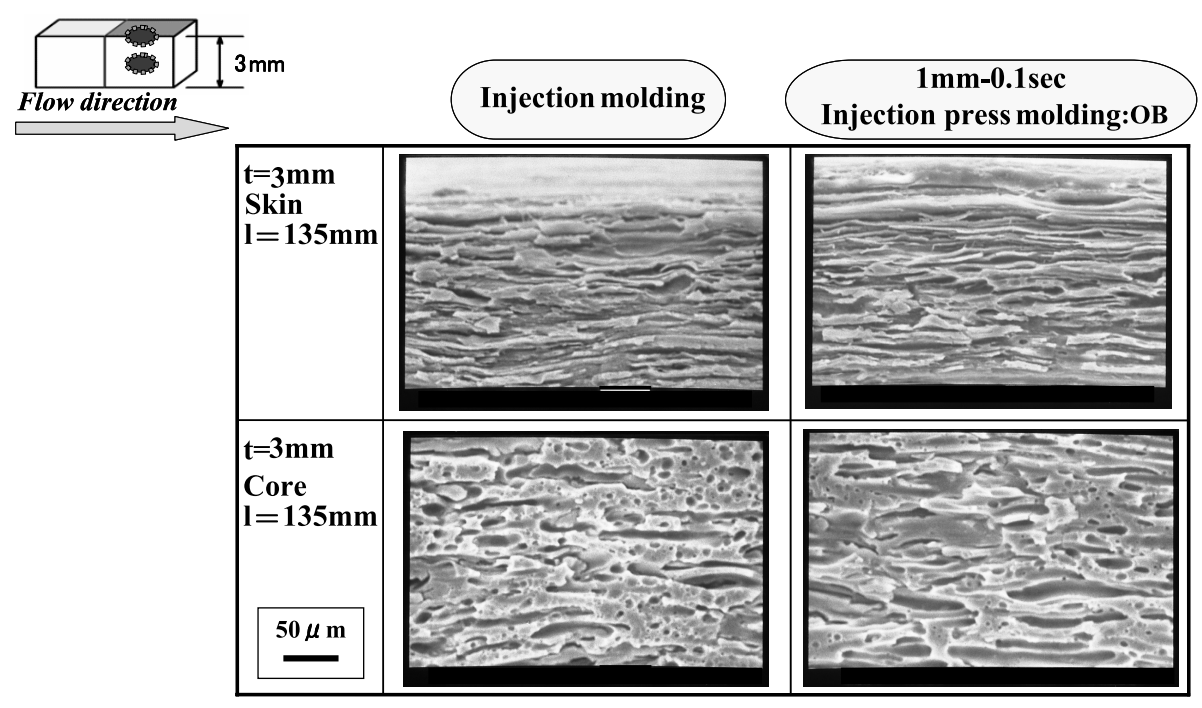

Fig. 6 SEM micrographs of normal injection molding and injection press molding with $3 \mathrm{~mm}$ thickness (compression distance : $1 \mathrm{~mm}$, compression time : $0.1 \mathrm{sec})$. 


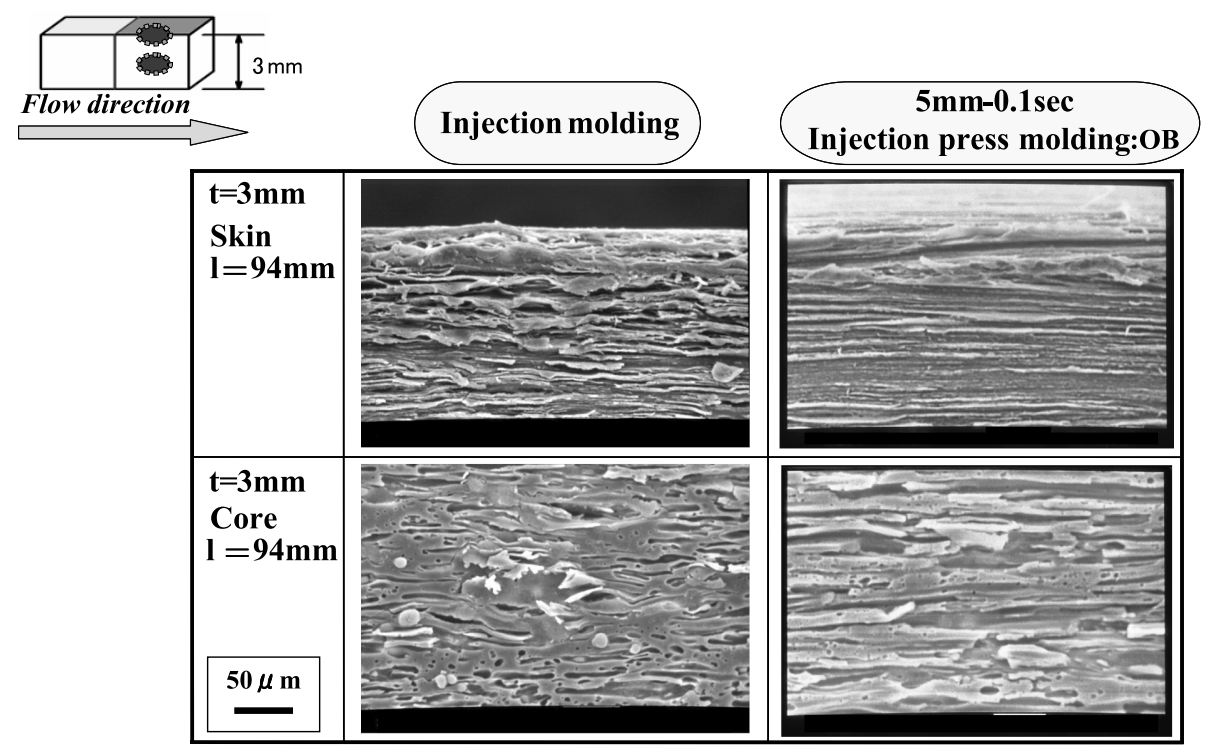

Fig. 8 SEM micrographs of normal injection molding and injection press molding with $3 \mathrm{~mm}$ thickness (compression distance : $5 \mathrm{~mm}$, compression time : $0.1 \mathrm{sec})$.
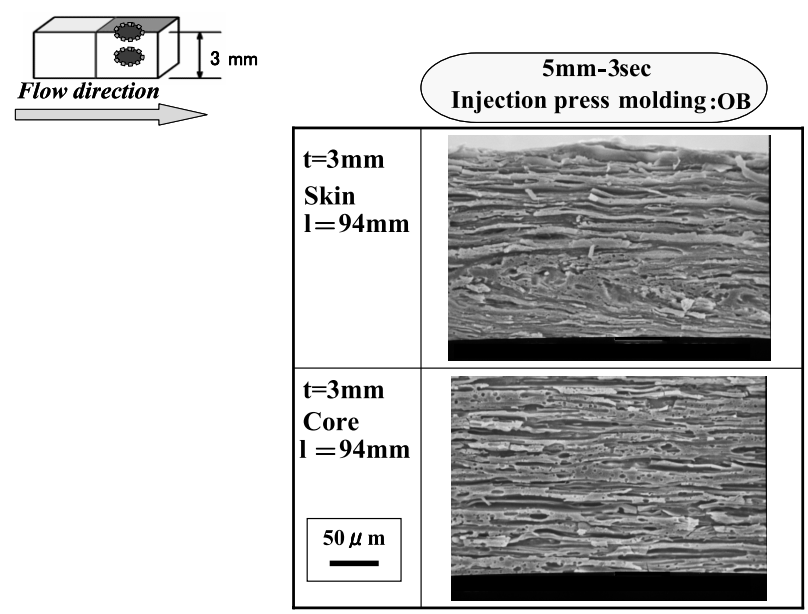

Fig. 9 SEM micrographs of normal injection molding and injection press molding with $3 \mathrm{~mm}$ thickness (compression distance $: 5 \mathrm{~mm}$, compression time : $3 \mathrm{sec})$.

\section{2 空孔測定}

次に内部構造の圧縮工程での偏平化を定量的に把握する ために，射出成形品と圧縮量 $5 \mathrm{~mm}$ 圧縮移行時間 $3 \mathrm{sec}$ の 射出プレス成形品の空孔の大きさを測定した．空孔を楕円 と考えその長径を $\mathrm{a}$ ，短径を $\mathrm{b}$ とし，スキン層からコア層 にかけて板厚方向に約 $200 \mu \mathrm{m}$ ずつ，7つの層にわけ，各 層において 25 ケ所の空孔の大きさを測定した. 図 10 に, $\mathrm{b}$ の各層での平均值を示す. $\mathrm{X}$ 軸はスキン層からコア層へ の 7 つの層を示し， $\mathrm{Y}$ 軸は空孔の $\mathrm{a}, \mathrm{b}$ の長さを示す.

射出成形品について，スキン層とコア層では空孔の長径 a は，ほぼ同じか若干コア層の方が短い傾向が見られた。

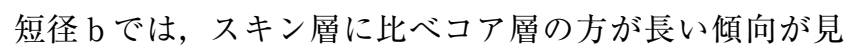
られた．射出プレス成形品では，長径 $\mathrm{a}$ はコア層ほど長く, 射出成形品よりも全体に横に長い空孔であることがわかっ

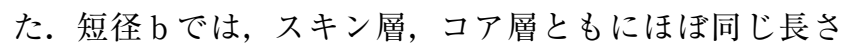

で，射出成形品に比べコア層で若干低い值であることがわ かった。

次に, 長径 $\mathrm{a}$ を短径 $\mathrm{b} て ゙$ 除し, 各層における空孔の偏 平度合いを算出した。 その結果を図 11 に示す. 数值 (a) b）が大きいほど空孔が細長く偏平している形状であり， 数值 $(\mathrm{a} / \mathrm{b})$ が小さいほど丸い空孔であることを示す.

射出成形品では, スキン層から，コア層につれて，数值 (a/b) が下がっている.このことは，スキン層よりコア 層の方が, 丸い空孔が多いことを示す.しかし, 射出プレ ス成形品では，射出成形品に比ベスキン層からコア層にか けて，偏平の度合いがほぼ同じかもしくは大きくなってい る.つまり, 射出プレス成形品の空孔は, スキン層, コア 層ともに細長く偏平しており, また, 数值 $(\mathrm{a} / \mathrm{b})$ も全体 に射出成形品に比べ大きいことから，平らに押しつぶされ 偏平化した空孔が多く存在することがわかる.

射出成形では成形品内部のひずみや，残留応力によるヒ ケ，ソリなどの成形不良に対して，ゲートからの射出圧力 で対処されてきた．また，場合によっては十分な効果が得 られず，最終的にゲート位置やゲート形状の変更，肉盗み などの成形品形状の変更により解決策を見出してきた. 今 回の研究では, 成形品内部の樹脂流動方向に平行な断面を 観察したが，射出プレス成形では，ゲートからの射出圧力 に型締めによる圧縮圧力を加えることによって，成形品の 流動方向において内部構造の均質化を可能とすることがわ かった．実際に生産されている成形品の形状は複雑なため, 成形品内部の樹脂流動はさらに多様と考えられるが，少な くとも一流動方向において内部構造が均質化することは, 成形品内部のひずみや, 残留応力の軽減に有効に働き, 射 出プレス成形がヒケやソリなどの成形不良に有効とされる 理由の一因であると考えられる.

\section{4. 結言}

本研究では, 射出成形と射出圧縮成形の一技法である射 


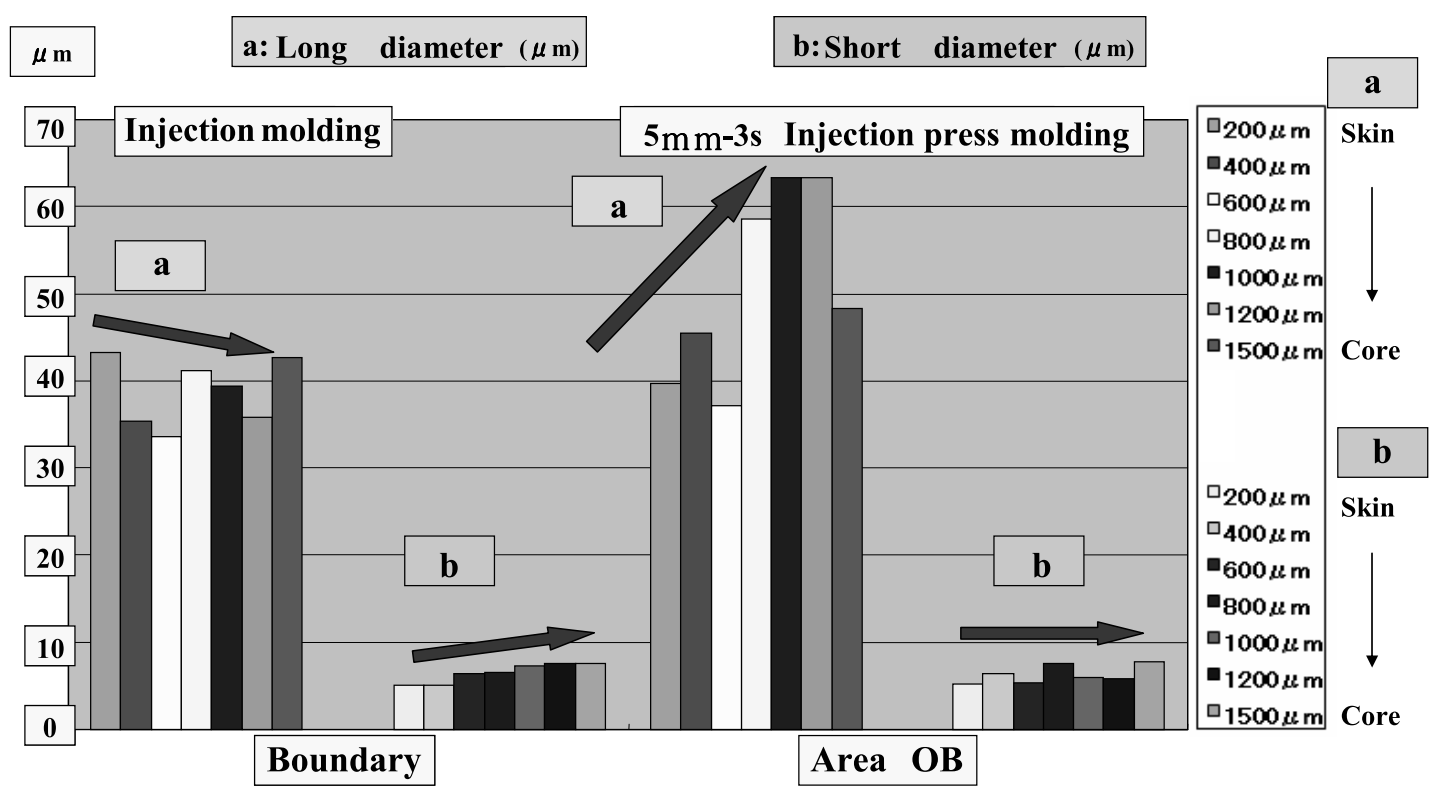

Fig. 10 Size distribution of Empty holes

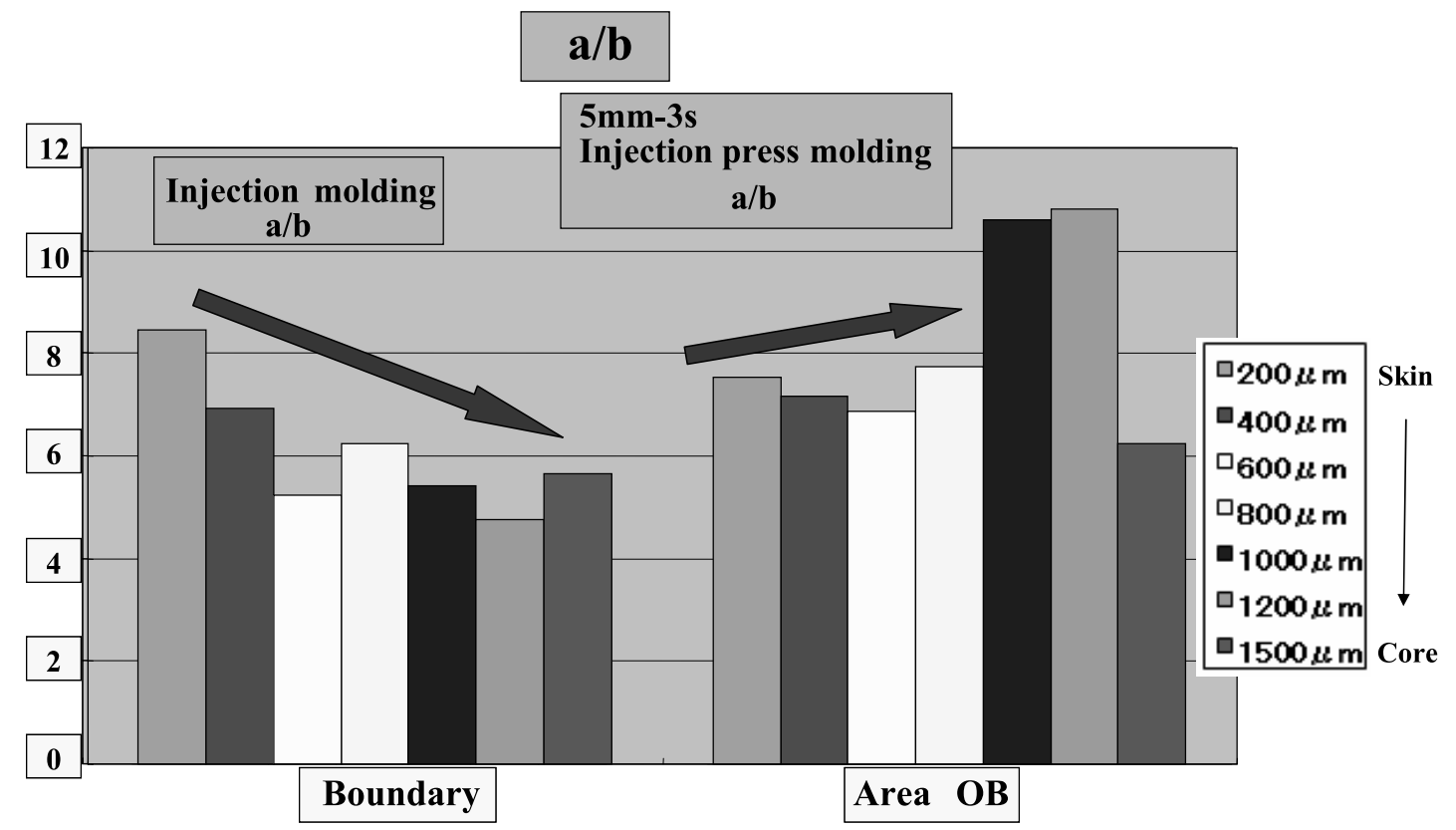

Fig. 11 a/b rations of Empty holes

出プレス成形における成形品の内部構造を観察することに より,その相違を検討した.その結果, 以下のことがわかった。

1 ）圧縮動作を加えた射出プレス成形品は, 特にコア層に おいて射出成形品とは異なる内部構造を示した。

2 ）射出成形品ではコア層で丸い空孔が多く存在したが, 射出プレス成形品では，コア層でもスキン層と同様に 流動方向に細長く偏平形状に変形した様相が観察され, 板厚方向にスキン層, コア層ともに均質な内部構造を 有することが明らかとなった。

3 ）圧縮条件の内部構造の均質化への影響は, 圧縮移行時 間よりも圧縮量の大小が大きく影響していることがわ かった。

\section{参 考 文 献}

1 ）伊澤梖一：プラスチック成形加工による高機能化 (2003)，シーエムシー

2 ) 松岡 徹, 小林智明, 片桐英雄, 泉 善一郎：成形加 エシンポジア’06, 211(2006)

3 ) 鎌田 悟, 工藤 素, 守時 一, 小山清人：成形加工, 11 (10)，856(1999)

4 ）鎌田 悟, 工藤 素, 守時 一, 小山清人：成形加工, 12 (6) , 332(2000)

5 ) http : //www.cybernet.co.jp/plamedia/product/mol dstudio3d.shtml 